\title{
The Influence of the Council of Europe's Policy on the Development of Legal Regulation of the Russian Transport System
}

\author{
Natalia V. Fedorenko ${ }^{1}$, Svetlana E. Hejgetova ${ }^{2}$
}

\begin{abstract}
:
In recent decades, not only public opinion but also the majority of State's national legislation and international agreements aimed at modernizing transport systems of the members of the Council of Europe, with a view to improve the spatial organization.

The most important factor in determining the particular attention of the Council of Europe to transport problems, is to enhance the safety and quality of transport services and finally to increase the importance of environmental criteria.
\end{abstract}

This article discusses the issues of formation and development of the transport legislation of Russia on the basis of international and European standards.

Keywords: Vehicle, transport, transportation, security, the environment, the quality of transport services.

\footnotetext{
${ }^{l} D S c,$. Soc. n., Professor of the Department of Civil Process of Rostov University (EDUCATIONAL)

${ }^{2}$ Corresponding author, Ph.D. of Law, A/Professor of the Civil Process of Rostov University (EDUCATIONAL), Associate Professor of Civil and Business Law of Russian Presidential Academy of National Economy and Public Administration (RANEPA), Affiliation ID: 60016781,e-mail: kse2562@mail.ru
} 


\section{Introduction}

World practice has shown that during the period the implementation of international integration projects the value of the importance of transport has been increased. The geographical position of the EU and Russia, the dynamics of European integration in recent years (new EU Member), defines an important place in Europe's transport policy in the development of European-Russian relations. In view of the tasks for implementing foreign policy, Russia is taking active steps to use its unique geographical location to increase transit in order to optimize the development of trade and economic relations between Europe (Decree of the President of the Russian Federation. 2016). Sustainable transportation is a guarantee of the unity of the economic space, free movement of goods and services, competition and freedom of economic activity, ensuring the integrity of Russia and its national security and improving the conditions and the standard of living of the population.

The transport policy of the EU formation has been formaleted for a long period of time. A former member of the Office of the Commissioner for Transport of the European Commission, describes the role and the place of the common transport policy in European history as a time of missed opportunities and a lack of full ETP with the most unfortunate chapters in the history of the European integration (Humphreys, 2011; Akopova et al., 2017; Papadaskalopoulos et al., 2015).

The European system of supranational regulation of transport activities is a unique experience for the Russian Federation, before the legislation faces similar challenges (White, 2013). Research scientists have identified weaknesses in the implementation of the provisions of the EU transport policy. The problematic issues of this policy include difficulties in formation of competition on the single market, to form unique transport services and the insufficient use of public-private partnership mechanism (Pak and Polyanova, 2015). Currently, the strategy of the transport development in the European Union, is aimed at the formation of modern transport systems. These systems must match occurred changes in the structure of the European and world economy. The European experience of legal regulation of transport activities, with the documents of the Council of Europe have influenced the formation and the development of the transport system in Europe. These documents have a substantial impact and legal regulation of the transportation industry in Russia (Dmitrishina and Uskov, 2015).

\section{Materials and methods}

The Council of Europe, founded in 1949, is an international organization that aims to ensure cooperation between members-states. The present composition of the Council of Europe includes 47 States. The Russian Federation joined the Council of Europe in February 1996. With the ratification in March 1998 the year of the European Convention for the protection of human rights and fundamental freedoms, Russia reaffirmed its commitment to the ideals and principles of humanism and democracy 
and expressed its willingness to bring its legislation into conformity with the requirements of the international European Community. In chapter I of the Statute of the Council of Europe devoted to the objectives pursued by the Council of Europe, it is stated that the purpose of this organization is to implement a closer Union between its members for the protection and the promotion of the ideals and principles which are their common heritage by facilitating their economic and social progress (Statute of the Council of Europe, 1949). This purpose is achieved by considering issues of common interest, the conclusion of agreements, joint action in the economic, social, cultural, scientific, legal and administrative fields, as well as by protection and promotion of human rights and fundamental freedoms. The problem of the protection of human rights and freedoms over time became the main issues of the Council of Europe. Today, its purpose is defined as building a Europe without dividing lines, based on the principles of democracy, human rights and the rule of law. The Council of Europe adopted a number of important documents that influenced the national transport legislation of the member-states forming the basis for the legal regulation of transport activities in the EU.

In 1971 the Committee of Ministers of the Council of Europe adopted resolution 71 (28) "The deprivation of the right to drive a vehicle" which stated that road traffic safety control essential road violations through appropriate means (The Council of Europe and Russia. 2004). As a mean of influencing the traffic violator in addition to educational measures, the Council of Europe recommended the use of deprivation of the right to drive a vehicle. The resolution emphasizes that this measure should be applied taking into account the personality of the driver and the other circumstances of the particular case. The procedure has to guarantee the right to protection, in particular the right to be heard and the right to appeal. The Council of Europe has repeatedly drawn attention in its documents on traffic growth, the growth of transport offences. Since one of the objectives of the Council of Europe is to achieve unity among its members, with a view to ensuring safety, attention was drawn to the establishment of the unified laws penalizing traffic offences. In many countries, driving under the influence of alcohol is a frequent cause of accidents. In 1973, was adopted the resolution "on the punishment of road offences". This document contains recommendations for harmonization of the legislation of the Member States of the Council of Europe in the field of responsibility for driving under the influence of alcohol and the use of punitive sanctions. The Governments of the member-states of the Council of Europe have a duty every 5 years to send notification to the Secretary General of the Council of Europe the notifications on measures taken to implement that resolution.

Russia pursuant to resolutions of the Council of Europe has made substantial amendments to the national regulations, such as the code of administrative offences of the Russian Federation, federal law on road traffic safety and a number of others. This law defines the legal basis for ensuring road traffic safety in the Russian Federation. Purpose of the Act is the protection of life, health and property of citizens, the protection of their rights and lawful interests of society and the State by 
preventing traffic accidents, reduce the severity of their consequences. Code of the Russian Federation on administrative offences contains chapter 12 administrative violations in the field of road traffic. Resolutions of the Council of Europe formed the basis of the transport policy of the European Union and implemented in its documents, which in turn influenced the legislation of Russia.

In the year 2001 the European Commission has adopted the white paper, which contains a section on European transport policy up to 2010 with certain solutions (White Paper, European transport policy for 2010). This document outlined the main objectives of EU transport policy by changing the balance between the various modes of transport, the removal of bottlenecks in the transport infrastructure, the transport policy orientation to its users getting the effect of the globalization of transport. The document contains measures for realization of tasks.

In 2006 the European Commission has revised transport prospects in the EU. As a result, the European Commission approved a plan for the development of the transport industry to the year 2020 .

In March 2011, the European Commission adopted a new strategy document in the field of Transport-White Book "Transportation-2050". At the same time, the subheading white paper reads as follows: "plan for the establishment of a single European transport space- the pursuit of competitive and resource-saving transport system" (Statute of the Council of Europe, 1949).

The Europeans have set two ambitious goals. On the one hand to build a single transport market while on the other, to increase the level of mobility while reducing harmful emissions into the atmosphere. For the sake of this goal, the European Commission is planning a radical transformation in the transport system on the continent.

\section{Results}

EU policy in the field of transport at the present stage is aimed at solving the problems associated with the lack of harmonic development of the overall transport system in Europe. These problems lies in the use of different modes of transport, security and quality of service, reducing harmful environmental effects of transport on the surrounding natural resources. The most important objectives of transport policies include establishing universal standards of transport infrastructure throughout the EU and, on this basis, the development of intermodal transport corridors. The importance in the development of the transport system has been given to the development of information security. Wide spread got satellite radio navigation, giving information on the exact location of the vehicle at any time. The establishment of an effective and progressive transport infrastructure to provide affordable, secure transport links between the territories within the country and in 
the world, the main task of the development of transport in the Russian Federation (The Act of the Government of the Russian Federation 2008).

Currently in Russia there is control and technological infrastructure of a gosystem "Platon" and GLONAS. Director of the Department of State policy in the field of road infrastructure of the Ministry of transport of Russia Igor Kostyuchenko, in his speech at a meeting of the Ministry in December 2017, noted that the introduction of system of "Platon" enabled to form a transparent market cargo transportation. The actual data are obtained on the number of carriers and the structure of the truck owners, among which over $60 \%$ are physical persons of which $15 \%$ of the funds collected by the "Platon System" came from foreign carriers. Based on data provided by the system operator "Platon" in regulatory authorities, investigations are carried out to identify customs violations. The introduction of these systems allows the use of digital technology for sealing the electronic documentation that significantly reduce the time of cargo delivery, customs checks and improving transport safety. These technologies will create a digital transport corridor for international cargo transit via Russia. Currently, the Ministry of transport of the Russian Federation is developing a regulation on the application of electronic navigational seals of the international transport of goods by road and rail (www.mintrans.ru 2018).

In 2017, the Ministry of Transport of the Russian Federation prepared a draft law on unified requirements for automated systems weight control on the roads in the Russian Federation. In the draft law included proposals received from market participants. Carriers have proposed the introduction of a system of warning drivers about detected violations product options on a course of movement, as well as information on existing areas (playgrounds, recreation road service objects), where drivers can eliminate violation and further movement in compliance with the law.

In Russia the construction of transport infrastructure is a public-private partnership mechanism. So, for example, Russian Development Bank, Foreign Economic Affairs (Vnesheconombank) Federal Center and project financing in February 2018 concluded an agreement on infrastructure development as crossing points in State borders. The agreement represents a fundamentally new and extremely topical direction of communication, and is the first experience of joint work of the Government and financial institutions in the area of resettlement points. Mechanisms of concessions and public-private partnerships are currently the main instruments to attract extra budgetary funding in transport projects, have several advantages over traditional public procurement. Firstly, this is a fair allocation of risk, which provides the interest of the parties in good faith in the performance of their obligations. Thus, an investor who is responsible for the establishment and operation of transport infrastructure with interested objects at the design stage, ensuring optimal technical and price solution. At the same time, embodied in relevant agreements financial obligations of the public hand, allow investors to structure the long-term financing of projects. Therefore, mechanisms of concessions and public- 
private partnerships for expensive transport projects attracted the attention of increasing investors.

Disability issues are a priority of transport policy of the State, including the activities of the law enforcement agencies of the Russian Federation. At present, extremely high levels of persons with disabilities who require the use of vehicles, but the present situation and the existing problems on the roads in administrative law are becoming obstacles (Fisakov, 2016). In Russia the State program "Wednesday" is for people with disabilities. Our believe is that it should contain not only the benefits and allowances for this category of citizens, but also the legal mechanisms they support and control. The need for the use of persons with disabilities requires vehicles to create such legal "Wednesday", in which every person, regardless of status and physical ability, has unhindered access to any objects of social, public transport and other infrastructure and can move freely on any selected route.

\section{Conclusions}

The European experience of forming a single mechanism for the regulation of transport activities is characterized by spatial-functional criteria that undoubtedly allows you to adapt the rules, regulations and procedures for the regulation of transport industry in Europe to other regions and especially in Russia. Analysis of the legislation showed that the main trend in the development of transport law of Russia in the 21 st century is its internationalization or homogenization through close interaction with European States. The legal norms of Russian is the law corresponding to the so-called supranational legal standards.

Research shows that "the most important practical task of legal regulation of transport is to optimize the transport legislation of Russia. Should resolve conflicts between statutes and codes of transport, various federal laws in the field of transport and the rules of civil law as well as international standards” (Hejgetova, 2014).

Selection of development directions of legal regulation of the Russian transport system is based on the prediction of long-term socio-economic development of the Russian Federation for the period up to the year 2030. Legal regulation is based on budget messages of the President of the Russian Federation to the Federal Assembly of the Russian Federation, the Scenic conditions of long-term socio-economic development of the Russian Federation up to the year 2030, legislative and other normative legal acts in the field of defence and national security of the Russian Federation.

Taking into account the accession of the Russian Federation to the World Trade Organization, takes into account strategic documents defining the perspective directions of development of the economy and social sphere of Russia's regions and industries. Among them the transport system of the country as a whole and the individual modes of transport, the prospects for the development of transport and 
logistics infrastructure in addition to the prospects for international transport integration.

\section{References:}

Akopova, S.E., Przhedetskaya, V.N., Taranov, V.P., Roshchina, N.L. 2017. Marketing Mechanisms for the Development of Transport Infrastructure of Russia and the EU. European Research Studies Journal, 20(1), 188-197.

Code of the Russian Federation offences. 2016. Out of N 195-FZ published on the official Internet-portal of legal information http://www.pravo.gov.ru

Decree of the President of the Russian Federation. 2016. Out of N 64 on approval of the concept of foreign policy of the Russian Federation.

Dmitrishina, E.V. and Uskov, A.D. 2015. The Issues of Covering Science and Technical Policy of Modern Russia in the Strategic Planning Documents. European Research Studies Journal, 18 (4), 57 -74.

Fisakov, M.Yu. 2016. Protection of the rights and legitimate interests of disabled road users: Problems of theory and practice. Social and Pension Law, 3, 31-34 (in Russian).

Hejgetova, S.E. 2014. Improvement and development of the transport legislation of Russia in the current economic conditions of Modern economical system: Problems compete and mutually beneficial cooperation in the economic and legal fields. A collection of articles of the international scientifically-practical Conference. Ed. G.b. Kleiner, H.A. Konstantinidi, V.V. Sorokozherdeva, Z.M. Hashevoj. Krasnodar, JuIM, 156161.

Humphreys, M. 2011. Sustainability in European Transport Policy. London and New York, Routledge, p. 150.

Pak, E.V., Polyanova, T.N. 2015. Common Transport Policy of the European Union: A Road Map for the Eurasian Economic Union. Mgimo University Bulletin, 3(42), 199-209 (in Russian).

Papadaskalopoulos, A., Christofakis, M. and Nijkamp, P. 2015. The Coastal Shipping Network in Greek Insular Space: Reorganising it Towards a "Hub and Spoke" System Using Matrices of Flows and Connectivity Matrices. European Research Studies Journal, 18(2), 29-44.

Resolution of the Government of the Russian Federation 2016. Out of N 1297 on approval of the State program of the Russian Federation "Wednesday" in the years 2011-2020". Published on the official Internet-portal of legal information http://www.pravo.gov.ru

Statute of the Council of Europe. 1949.

The Act of the Government of the Russian Federation 2008. About transport strategy of the Russian Federation, p. 1734.

The Council of Europe and Russia. 2004. Collection of documents-m.: Law books.

The Federal law. 1995. Out of N 196-FZ Rroad safety, published on the official Internetportal of legal information http://www.pravo.gov.ru of the administrative

White, V.S. 2013. Transport legislation of Russia and other States of the EU, SCO. EURASEC, 47-50.

White Paper. European transport policy for 2010: time to mission of the European Communities. Brussels, (20final ) www.libfox.ru

White Book "Transportation-2050" www.eurasiancommission.org

www.mintrans.ru 2018. 